UDC 541.13.544.65

\title{
ELECTODEPOSITION OF MOLYBDENUM FROM ALKALI ELECTROLYTE
}

\author{
U.M.Gurbanova \\ M.Nagiyev Institute of Catalysis and Inorganic Chemistry, NAS of Azerbaijan \\ uqurbanova92@gmail.com
}

Received 13.05.2019

\begin{abstract}
The process of reducing molybdate ions from an alkaline electrolyte was investigated by removing cyclic and linear polarization curves. The reduction of molybdate ions occurs predominantly from heptomolybdate ions, which are formed as a result of the polymerizing action of ammonium ions on molybdate ions. The formation of a large amount of heptamolybdates in an alkaline solution accelerates the reduction reaction of molybdate ions. An analysis of the polarization curves at different temperatures made it possible to reveal that the process of electroreduction of molybdate ions from an alkaline electrolyte is accompanied by diffusion polarization.
\end{abstract}

Keywords: electrodeposition, molybdate ions, heptomolybdates, polarization.

doi

\section{Introduction}

Despite numerous fundamental studies on the processes of electroreduction and electrooxidation of transition metals, interest to them have not waned for many decades.

Because of its excellent properties, molybdenum is of great interest for the hydrogen evolution reaction (HER) due to its high corrosion resistance $[1,2]$. Doping of stainless steel by molybdenum improves its properties due to the formation of a passive film on the electrode surface, which leads to its high resistance to pitting corrosion in corrosive environments [3]. Studies of molybdenum alloys with metals of the iron subgroup have confirmed that an increase in the Mo content in the composition of electrocatalysts for the electrolysis of water increases their corrosion resistance $[4,5]$. Molybdenum alloys can be obtained using plasma or thermal spraying, thermal decomposition or electrochemically method [6]. The production of molybdenum alloys by metallurgical methods is inconvenient due to the oxidation at the crystallization stage and the high melting point of molybdenum itself [7].

The most acceptable method of producing molybdenum alloys is an electrochemical method, which makes it possible to obtain films of the desired composition by changing the composition of the electrolyte and the conditions of electrolysis [8-10].

Successful joint electrodeposition of metals is not possible without knowledge of the mechanism and kinetics of electrode processes are occurring during their deposition. In addition, it is necessary to determine the nature of polarization, namely these studies make it easy to choose electrolysis conditions, under which deposition of the desired composition and quality can be obtained at the cathode.

Molybdenum, like other transition metals, is very difficult to deposite independently from aqueous solutions, but they are reduced to the metal in the presence of coprecipitates. The mechanism of the complete reduction of molybdenum is directly related to the mechanism of alloy formation in the refractory metal-metal-codeposition system. Despite many studies conducted in the field of molybdenum deposition, there is still no precise definition of the mechanism of deposition and a stable electrolyte for the electrodeposition of this metal. The reduction of molybdenum (VI) ions was investigated from sulphate electrolytes [11], from alkaline and weakly acid electrolytes [12], and from aqueous solutions [13].

This work presents studies of the nature of polarization in the deposition of molybdenum from an alkaline ammonia electrolyte by removing linear and cyclic potentiodynamic polarization curves at various concentrations of the main component, potential sweep rate and temperature.

\section{Experimental technique}

Electrochemical reduction of molybdate ions have been carried out from ammonia electrolyte. At the end, the required amount of sodi- 
um molybdate has been dissolved in an ammonia solution $\left(7 \mathrm{M} \mathrm{NH} \mathrm{N}_{4} \mathrm{OH}\right)$. Polarization curves were taken on an IVIUMSTAT Electrochemical Interface potentiostat using a classic threeelectrode cell with a capacity of $100 \mathrm{ml}$ equipped with a water coating, which allows to maintain constant electrolyte temperature while studying the temperature dependence of molybdate ion recovery using a universal UTU-4 ultrathermostat. A platinum wire served as the working electrode, a $4 \cdot 10^{-3} \mathrm{dm}^{2}$ surface, a platinum plate as an auxiliary electrode with a surface of $0.04 \mathrm{dm}^{2}$; a silver chloride electrode has been used as a reference electrode.

\section{Experimental part}

It is known that hexavalent molybdenum ions can be in solution in the form of monomolybdates and polymolybdates [14]. Monomolybdate ions $\left[\mathrm{MoO}_{4}\right]^{2-}$ are predominantly present in solutions containing an excess of alkali, but polymerization occurs in ammonia solutions of molybdate ions $\mathrm{Mo}_{7} \mathrm{O}_{24}{ }^{6-}$, with formation heptomolybdates [15], which at $\mathrm{pH}>6(\mathrm{pH} 6.75)$ are converted into $\mathrm{MoO}_{4}{ }^{2-}[16,17]$. The electrochemical behavior of aqueous solutions containing molybdate ions has been studied in an electrolyte containing $\mathrm{Na}_{2} \mathrm{MoO}_{4} \cdot 2 \mathrm{H}_{2} \mathrm{O}$ at $\mathrm{pH}$ 1111.2. A visual analysis showed that a dark film is formed on the cathode surface at a potential of $(-0.15 \div-0.17) \mathrm{V}$ during cathode polarization. The deposition obtained at the cathode is

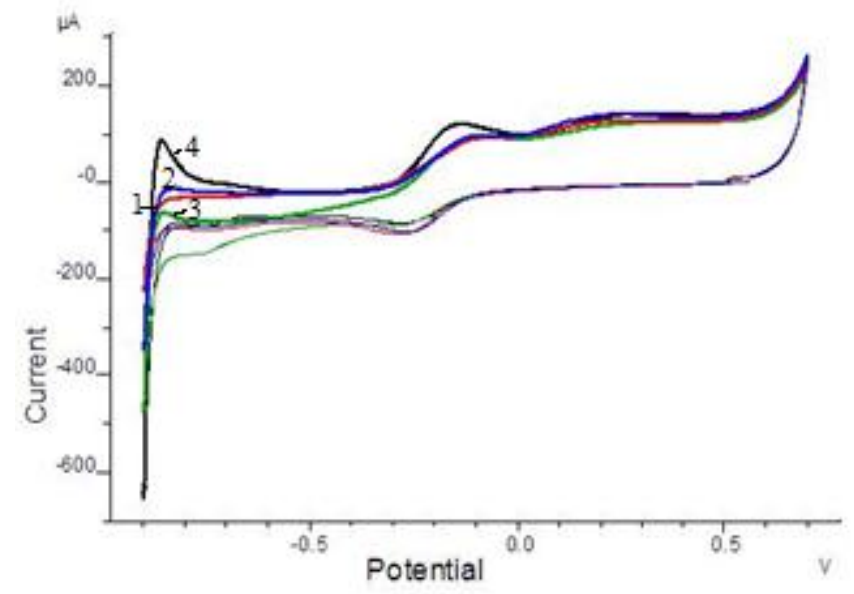

probably a mixture of several molybdenum compounds of intermediate valencies. In this case, the inclusion of a water molecule in the sediment is possible and, therefore, a dark film on the electrode surface is most likely a mixture of oxides and basic oxides of three, four and five valent molybdenum, the main part of which is $\mathrm{MoO}_{2}$. It is known that three valent molybdenum exists in solution in the form of $\left[\mathrm{Mo}_{2} \mathrm{O}_{4}\right]^{2+}$ cations, which disproportionate in strongly alkaline solutions with the formation of Mo (IV) and Mo(VI) [15].

The effect of molybdenum concentration on the course of polarization curves during its deposition was investigated. In Figure 1 the polarization curves of molybdenum electrodeposition at different concentrations of $\mathrm{Na}_{2} \mathrm{MoO}_{4} \cdot 2 \mathrm{H}_{2} \mathrm{O}$ in the electrolyte, which varied in the range of $(0.057-\div-0.138) \mathrm{M}$, are shown. The value of the stationary potential of the electrode remained almost unchanged. At all concentrations at a potential of $(-0.26 \div 0.28) \mathrm{V}$, a small plateau appears, which apparently corresponds to the formation of a $\mathrm{MoO}_{2}$ film on the cathode.

At concentrations of $\mathrm{Na}_{2} \mathrm{MoO}_{4} \cdot 2 \mathrm{H}_{2} \mathrm{O}$ from 0.057 to $0.092 \mathrm{M}$, the height of this plateau, corresponding to the formation of $\mathrm{MoO}_{2}$, almost does not change and makes up to $9.286 \cdot 10^{-5} \mathrm{~A}$, but at a concentration of $0.138 \mathrm{M}$ its height increases to about $20 \%$ and makes up to $1.182 \cdot 10^{-4} \mathrm{~A}$ and the recovery potential shifts somewhat.

Fig.1. Polarization curves for the reduction of molybdate ions on a platinum electrode depending on the concentration of $\mathrm{Na}_{2} \mathrm{MoO}_{4} \cdot 2 \mathrm{H}_{2} \mathrm{O}: 1$ $0.057,2-0.069,3-0.092,4-0.138$; the electrolyte composition (M): $\mathrm{H}_{3} \mathrm{BO}_{3}-0.1, \mathrm{NH}_{4} \mathrm{OH}-7$, $\mathrm{Na}_{2} \mathrm{MoO}_{4} \cdot 2 \mathrm{H}_{2} \mathrm{O}$ of different concentrations (curves $1-4$ ); $E_{\mathrm{V}}=0.02 \mathrm{~V} / \mathrm{s}, \mathrm{pH}-11.2, T-298 \mathrm{~K}$. 
According to the Purbe diagram [18] in the study area $\mathrm{pH} \mathrm{MoO}_{2}$ is the most stable compound. In view of the fact that molybdenum oxide compounds formed on the surface of the cathode are a good catalyst for the reaction of hydrogen evolution from aqueous solutions [19], their formation as a result of the reduction of molybdate ions contributes to the evolution of hydrogen aon the cathode.

At values of the potential $(-0.74-0.76) \mathrm{V}$, the second plateau appears on the polarization curves, corresponding coreduction of molybdenum oxide to molybdenum. At values of the potential of $(-0.91-0.92) \mathrm{V}$, the rapid release of hydrogen begins, thereby preventing the deposition of molybdenum on the cathode surface, that agrees with the literature data [20].

At the reverse of the curve at the potential of $-0.86 \mathrm{~V}$, the molybdenum film dissolves, and at the potential of $-0.15 \mathrm{~V}$, the molybdenum oxide, deposite on the electrode surface dissolves. It is known that if a significant amount of hydrogen ions are involved in cathodic reactions, the from reaction potentials strongly depend the $\mathrm{pH}$ of the solution. It can be assumed that hydrogen evolution contributes to the reduction of $\mathrm{Mo}(\mathrm{V})$ in $\mathrm{Mo}(\mathrm{IV})$ with the formation of $\mathrm{MoO}_{2}$, from which molybdenum is released almost simultaneously with hydrogen.

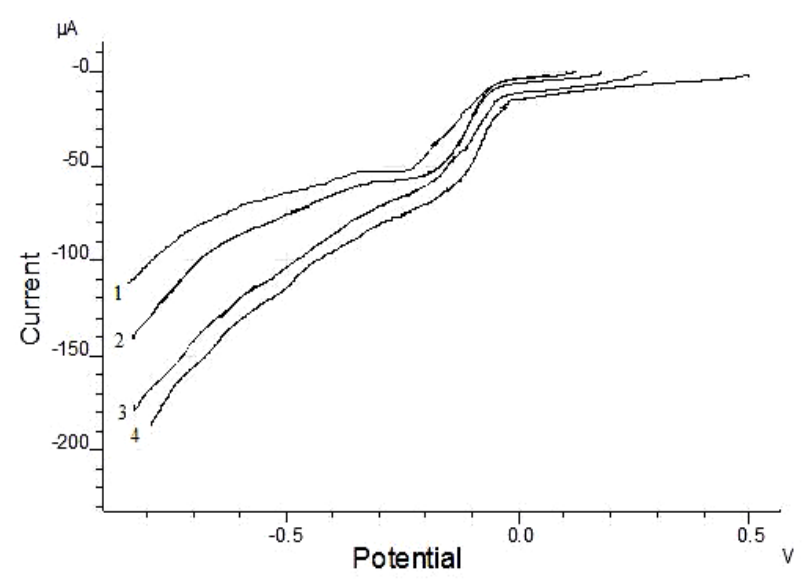

Fig.2. The dependence of cathode polarization curves for the reduction of molybdate ions on the temperature, K: $1-298,2-308,3-323,4-$ 333 at the platinum electrode: The composition of the electrolyte $(\mathrm{M}): \mathrm{Na}_{2} \mathrm{MoO}_{4} \cdot 2 \mathrm{H}_{2} \mathrm{O}-0.124$; $\mathrm{H}_{3} \mathrm{BO}_{3}-0.1, \mathrm{NH}_{4} \mathrm{OH}-7 ; E_{\mathrm{v}}=0.02 \mathrm{~V} / \mathrm{s}$.
On the polarization curves for the reduction of molybdate ions, the area of the limiting current at a potential of $-0.26 \mathrm{~V}$ is associated with the formation of a $\mathrm{MoO}_{2}$ film, the further reduction of $\mathrm{MoO}_{2}$ to $\mathrm{Mo}$ is difficult because of the catalytic properties of molybdenum dioxide coatings. Therefore, as soon as the first layers of molybdenum oxide are formed on the surface of platinum, the reduction of hydrogen ions begins. This process prevents further precipitation of molybdenum dioxide reduction products on the electrode surface.

In Figure 2 the polarization curves for the reduction of molybdate ions as a function of temperature have been shown. Studies were performed in the temperature range of (298333) K. It can be seen from the curves that the increasing in the electrolyte temperature leads to the increase in the height of the plateau corresponding to the formation of molybdenum oxide, but the plateau itself is already weakly expressed. This is apparently due to the release of ammonia from the ammonia electrolyte under the action of temperature. According to Figure 2, the dependence $\lg i$ versus $1 / T$ (Figure 3 ) has been constructed at various potentials, which had the straight forward character. The slope of these lines gradually increases with increasing cathode potential.

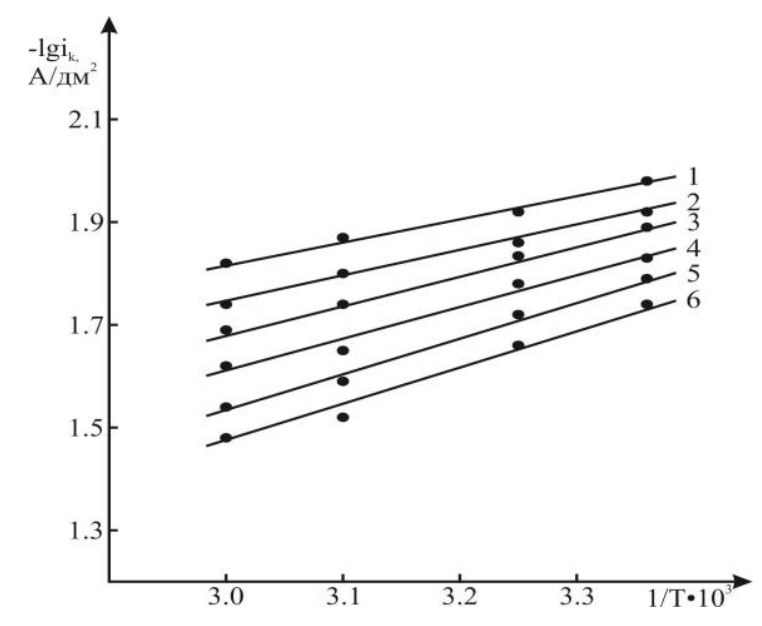

Fig.3. The dependence $\lg i_{\mathrm{k}}-1 / T, E(\mathrm{~V}): 1-$ $(-0.1), 2-(-0.2), 3-(-0.3), 4-(-0.4) ; 5-$ $(-0.5), 6-(-0.6)$. 
Straight lines 1 and 2, corresponding to potentials -0.1 and $-0.2 \mathrm{~V}$ are nearly parallel, their slope is less than the slope of straight lines 5 and 6 , corresponding to potentials -0.5 and $0.6 \mathrm{~V}$, and straight lines 4 and 3, corresponding to potentials -0.3 and $-0.4 \mathrm{~V}$ occupy the intermediate position. Based on the data in Figure 3, by the slope of the straight lines depending on $\lg i$ versus $1 / T$, the activation energy was calculated for the molybate ion reduction reaction using the formula $\mathrm{A}_{\text {eff }}=4.64 \operatorname{tg} \alpha$; the activation energy for the molybdate ion reduction reaction was determined to be $17.2-20.8 \mathrm{~kJ} / \mathrm{mol}$. Such an activation energy value corresponds to processes where the diffusion stage is the limiting stage.
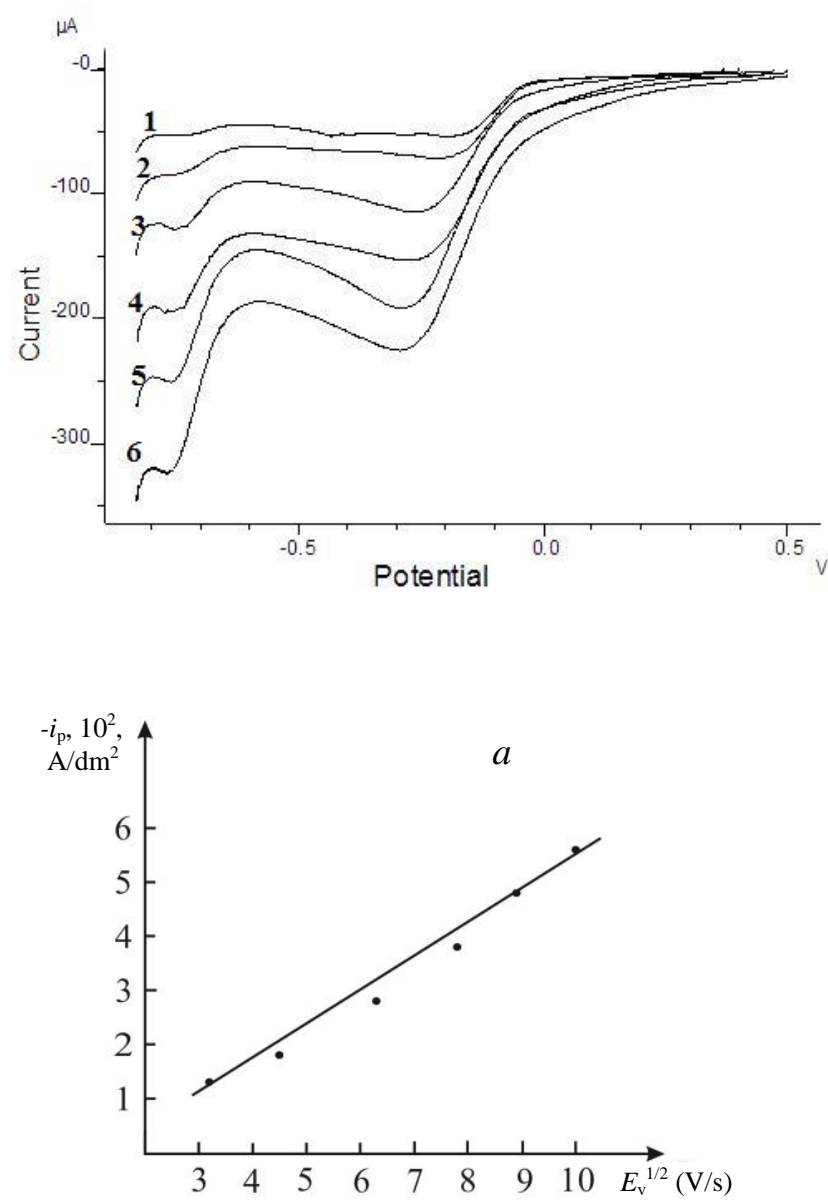

The effect of the potential sweep rate on the polarization curves of molybdenum has been also studied.

In Figure 4 the polarization curves of the electrostimulation of molybdate ions are presented as a function of the scanrate. The Figure shows that an increase in the sweep speed leads to an increase in the speed of the cathodic process, and the relationship between $i_{\mathrm{p}}$ and $E_{\mathrm{v}}{ }^{1 / 2}$, built on the basis of a series of polarization curves obtained at different potential sweep speeds for both processes occurring on the cathode surface, has a straightforward character (Figure 5).

Fig.4. The effect of the scanrate on the electroreduction of molybdate ions on a platinum electrode: The composition of the electrolyte (M): $\mathrm{Na}_{2} \mathrm{MoO}_{4} \cdot 2 \mathrm{H}_{2} \mathrm{O}-0.124, \mathrm{H}_{3} \mathrm{BO}_{3}-0.1$, $\mathrm{NH}_{4} \mathrm{OH}-7, T-298 \mathrm{~K}, E_{\mathrm{v}}(\mathrm{V} / \mathrm{s}): 1-0.01$, $2-0.02,3-0.04,4-0.06,5-0.08,6-0.1$.

Fig.5. The dependence of $i_{\mathrm{p}}-E_{\mathrm{v}}{ }^{1 / 2}$ in the recovery of molybdate ions from the electrolyte of this composition (M): $\mathrm{Na}_{2} \mathrm{MoO}_{4} \cdot 2 \mathrm{H}_{2} \mathrm{O}-0.124, \mathrm{H}_{3} \mathrm{BO}_{3}-0.1, \mathrm{NH}_{4} \mathrm{OH}-7 ; a$ ) for the reaction of formation of $\mathrm{MoO}_{2}$ at a potential of $-0.28 \mathrm{~V}, b$ ) for the reaction of Mo formation at a potential of $-0.76 \mathrm{~V} ; T-298 \mathrm{~K}$. 
Such a dependence suggests that the cathodic polarization for both processes has a diffusion nature Figure 5). It is possible that the diffusion limitations in the process of reduction molybdate ions are related to the fact that their reduction occurs mainly from heptomolybdate ions, which are formed as a result of the polymerizing action of ammonium ions on molybdate ions. These data completely coincide with the data of temperature studies.

Thus, as a result of investigation it has been revealed that the recovery of molybdate ions proceeds in stages. The first stage is the formation of three valent molybdenum compounds, which, being unstable in alkaline solutions, disproportionate with the formation of $\mathrm{MoO}_{2}$ and $\mathrm{MoO}_{4}^{2-}$ Increasing the temperature leads to the release of ammonia from the ammonia electrolyte and therefore it is advisable to conduct electrolysis at room temperature. $\mathrm{Ca}$ thodic polarization in the reduction of molybdate ions has a diffusion nature.

\section{References}

1. Badawy W.A., Feky H.E., Helal N.H., Mohammed H.H. Cathodic hydrogen evolution on molybdenum in $\mathrm{NaOH}$ solutions. Int J. Hydrogen Energy. 2013. V.38. No 23. P. 9625-9632.

2. Badawy W.A., Gad-Allah A.G., Abd El-Rahman H.A., Abou-Romia M.M. On the stability of anodic oxide films formed on molybdenum in various aqueous solutions. Surf Coatings Technol. 1987. V. 30. No 4. P. 365-373.

3. Stiefel E.I. Molybdenum and molybdenum alloys. Kirk-Othmer encyclopedia of chemical technology. New York. 2010. V. 16. P. 853-871.

4. Kublanovsky V., Bersirova O., Yapontseva Y., Cesiulis H., Podlaha-Murphy E. Cobalt-molybdenum-phosphorus alloys: electroplating and corrosion properties. Prot. Metals Phys. Chem. Surfaces. 2009. V. 45. No 5. P. 588-594.

5. Jovic B.M., Lacnjevac U.C., Jovic V.D., GajicKrstajic L.M., Krstajic N.V. On the kinetics of the hydrogen evolution reaction on $\mathrm{Ni}-\mathrm{MoO}_{\mathrm{x}}$ composite catalysts in alkaline solutions. J. Serbian Chem. Soc. 2012. V. 77. No 2. P. 211-224.

6. Abdel-Karim R., Halim J., El-Raghy S., Nabil M., Waheed A. Surface morphology and electrochemical characterization of electrodeposited $\mathrm{Ni}-$ Mo nanocomposites as cathodes for hydrogen evolution. J. Alloys and Compounds. 2012. V. 530. P. 85-90.
7. Donten M., Cesiulis H., Stojek Z. Electrodeposition of amorphous/nanocrystalline and polycrystalline Ni-Mo alloys from pyrophosphate baths. Electrochim. Acta. 2005. V. 50. No 6. P. 14051412.

8. Shervedani R.K., Alinoori A.H., Madram A.R. Electrocatalytic activities of nickel-phosphorous composite coating reinforced with codeposited graphite carbon for hydrogen evolution reaction in alkaline solution. J. New Mater Electrochem. Syst. 2008. V. 11. P. 259-265.

9. Daly P.B., Barry F.J. Electrochemical nickelphosphorous alloy formation. Int. Mater. Rev. 2003. V. 48. No 5. P. 326-338.

10. Tilak B.V., Tari K., Hoover C.L. Metal anodes and hydrogen cathodes: their activity towards $\mathrm{O}_{2}$ evolution and $\mathrm{ClO}_{3}{ }^{-}$reduction reactions. J. Electrochem. Soc. 1988. V. 135. No 6. P. 1386-1392.

11. Majidzade V.A., Guliyev P.H., Aliyev A.Sh., Elrouby M., Tagiyev D.B. Electrochemical characterization and electrode kinetics for antimony electrode position from its oxychloride solution in the presence of tartaric acid. J. Mol. Struct. 2017. V. 1136. P. 7-13.

12. Majidzade V.A., Alizade Sh.E., Aliyev A.Sh. Study of the kinetics of electrochemical reduction of bismuth ions. Nakhchivan State University. Scientific works. 2018. V. 92. No 3. P. 176-179.

13. Aliyev A.Sh., Majidzade V.A., Soltanova N.Sh., Tagiyev D.B., Fateev V.N. Some features of electrochemically deposited CdS nanowires. Chemical Problems. 2018. V. 2. P. 178-185.

14. Remi G. Kurs neorganicheskoi himii. T. 2. per. s nem. M.: Mir, 1972. $836 \mathrm{~s}$.

15. Pop M.S. Geteropoli- i izopolioksometallaty. Novosibirsk: Nauka. Sib. Otd-nie, 1990. 232 s.

16. Aveston J., Anacker E.W., Johnson J.S. Hydrolysis of molybdenum (VI). Ultracentrifugation, acidity measurements, and Raman spectra of polymolybdates. Inorg. Chem. 1964. V. 3. No 5. P. 735-746.

17. Mitchell P.C.H. Ullmann's encyclopedia of industrial chemistry, 5th ed. Willey-VCH. Germany. 1990. 675 (Ch. 7).

18. Spravochnik himika. 3-e izd., ispr. t. 3. L.: Himiia, 1964. $1008 \mathrm{~s}$.

19. Petrova M.L., Bojinov M.S., Gadjov I.H.. Electrodeposition of molybdenum oxides from weakly alkaline ammonia-molybdate electrolytes. Bulgarian Chemical Communications. 2011. V. 43. No 1. P. 60-63.

20. Syed R., Ghosh S.K., Sastry P.U., Sharma G., R.C.Hubli., Chakravartty J.K. Electrodeposition of thick metallic amorphous molybdenum coating from aqueous electrolyte. Surface and Coatings Technology. 2015. V. 261. P. 15-20. 


\section{QӘLəVİ ELEKTROLITDӘN MOLIBBDENIN ELEKTROKIMYəVİ ÜSULLA ÇÖKDÜRÜLMəSi}

\section{Ü.M.Qurbanova}

Təqdim olunan işdə molibdat ionlarının qələvi elektrolitdən elektroreduksiya prosesi tsiklik və xətti polyarizasiya əyrilərini çəkilməsilə tədqiq edilmiş̧ir. Molibdat ionlarının reduksiyası, əsasən, heptamolibdat ionlarından köməyilə baş verir ki, bu da ammonium ionlarının molibdat ionlarına polimerləşməsinin təsiri nəticəsində meydana gəlir. Qələvi məhlulunda heptamolibdat ionlarının daha çox miqdarda əmələ gəlməsi molibdat ionlarının reduksiya prosesini sürətləndirir. Molibdat ionlarının müxtəlif temperaturlarda çəkilmiş polyarizasiya əyrilərinin analizi göstərir ki, qələvi elektrolitdən bu ionların elektroreduksiya prosesi diffuzion polyarizasiya ilə müşayiət olunur.

Açar sözlor: elektroçökmə, molibdat ionları, heptomolibdat ionları, polarizasiya.

\section{ЭЛЕКТРООСАЖДЕНИЕ МОЛИБДЕНА ИЗ ЩЕЛОЧНЫХ ЭЛЕКТРОЛИТОВ}

\section{У.М.Курбанова}

В данной работе снятием циклических и линейных поляризационных кривых исследован процесс электровосстановления молибдат-ионов из щелочного электролита. Восстановление молибдат-ионов происходит преимущественно из ионов гептомолибдата, которые образуются в результате полимеризующего действия ионов аммония на молибдат-ионы. Образование большего количества гептамолибдатов в щелочном растворе ускоряет реакцию восстановления молибдат-ионов. Анализ поляризационных кривых при различных температурах позволил выявить, что процесс электровосстановления молибдат ионов из щелочного электролита сопровождается диффузионной поляризацией.

Ключевые слова: электроосаждение, молибдат-ионы, ионы гептомолибдата, поляризация. 